\title{
Phylogenetic classification of the major superfamily of membrane transport facilitators, as deduced from yeast genome sequencing
}

\author{
Bart Nelissen $^{\mathrm{b}}$, Philippe Mordant ${ }^{\mathrm{a}}$, Jean-Luc Jonniaux ${ }^{\mathrm{a}}$, Rupert De Wachter ${ }^{\mathrm{b}}$, André Goffeau ${ }^{\mathrm{a}, *}$ \\ ${ }^{a}$ Unité de Biochimie Physiologique, Faculté des Sciences Agronomiques, Université Catholique de Louvain, \\ Place Croix du Sud 2-20, B-1348 Louvain-la-Neuve, Belgium

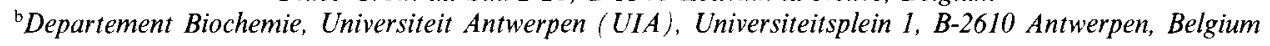

Received 16 November 1995

\begin{abstract}
From the approximately 5000 open reading frames presently identified by systematic sequencing of the yeast genome, 100 Saccharomyces cerevisiae transport proteins belonging to the major facilitator superfamily (MFS), were assigned to 17 families on the basis of extensive database searches and binary comparisons. These families include multidrug resistance proteins and transport proteins for sugars, amino acids, uracil/ allantoin, allantoate, phosphate, purine/cytosine, proteins, peptides, potassium, sulfate, and urea. Four new families of unknown function have been identified. For the sugar and amino acid transport proteins, alignments were made and phylogenetic trees were constructed allowing the identification of several clusters of proteins presumably exhibiting similar transport functions.
\end{abstract}

Key words: Transport protein; Yeast genome; Major facilitator superfamily (MFS)

\section{Introduction}

Transport proteins can be classified into several superfamilies, the members of which are found in all living species from mycoplasma to man. One of these transport protein superfamilies, is the major facilitator superfamily or MFS [1], characterized by two structural units of a 6 transmembrane-spanning helical segment, connected by a cytoplasmic loop, resulting in proteins with about 500 to 600 amino acids and 12 transmembrane helices. The proteins of the MFS superfamily have been divided into six families [2]. Other transport protein families that are characterized by a structural motif of 12 transmembrane-spanning helical segments include the amino acid-polyamine-choline (APC) family, and the sodium: solute symporter (SSF) family [2].

The sequence of the Saccharomyces cerevisiae genome is almost completed [3-5]. Because this is the first complete eukaryote sequence becoming available, Saccharomyces cerevisiae is very well suited for a study of the function and classification of transport proteins, which may serve as a model for other eukaryotes.

In this paper we have classified the 12 transmembrane-spanning transport proteins of the major facilitator superfamily. A preliminary grouping has been based on database searches of 12 transmembrane-spanning query sequences. The consistency of these groupings into families has been investigated by binary

*Corresponding author. Fax: (32) (10) 473872.

E-mail: GOFFEAU@FYSA.UCL.AC.BE comparisons of all retrieved amino acid sequences. Multiple alignments were made for the largest groups in order to study the relationships between the constituent proteins by tree construction.

\section{Methods}

\subsection{Classification into families}

The 1884 non-redundant open reading frames from the Saccharomyces cerevisiae chromosomes I, II, III, V, VIII, IX, XI and part of other chromosomes, available in March 1995, were retrieved from the EMBL, GenBank, PIR, SwissProt, MIPS, SYDB, and YPD databases. These sequences were first screened according to their number of transmembrane spans as predicted by the KKD algorithm [6], with the threshold value of 15 for the peripheral/integral odds as described by $[3,4]$. To be sure to include all 12 transmembrane-spanning proteins, all proteins with 8 or more predicted transmembrane spans were used.

A BLAST [7] search of all amino acid sequences with 8 or more predicted transmembrane spans was carried out by the BLAST e-mail server version 1.4 at the National Center for Biotechnology Information (Bethesda, MD). All sequences producing high-scoring segment pairs with a $P(N)<10^{-9}$ were considered to be closely related. All query sequences that had at least one closely related sequence in common, were placed in the same family. Those families that did not belong to the major facilitator superfamily (MFS) as deduced from their function in the BLAST results, e.g. the ATP-binding cassette (ABC) superfamily, were excluded from further analysis. All closely related yeast sequences that did belong to the MFS families but that were not yet in our dataset were retrieved. Starting from this dataset, the validity of each family was investigated by binary comparison of all protein sequences with each other. These binary comparisons were done with PRSS, a program for testing the significance of a protein sequence similarity, which belongs to the FASTA $[8,9]$ software package version 1.7. For each comparison, 100 shuffles were done. A protein sequence was assigned to a family when its PRSS P-value with at least one member of the family was below $10^{-9}$ (Goffeau et al., unpublished results). When suspected, frame shifts were detected and corrected with the software package DNA Strider version 1.2 (Centre d'Etudes Nucleaires de Saclay, France).

\subsection{Alignment of amino acid sequences}

The amino acid sequences of the sugar and amino acid permease family were aligned with the multiple alignment program PILEUP, which belongs to the Wisconsin Sequence Analysis Package [10], version 8.0.

\subsection{Phylogenetic tree construction}

On the basis of the alignments dissimilarity matrices were calculated. Dissimilarities were converted into distances, assuming $[11,12]$ that the rate of amino acid substitution follows the Poisson distribution, using the equation $D_{\mathrm{AB}}=-\ln (1-S)$, where $D$ is the evolutionary distance between two proteins $\mathrm{A}$ and $\mathrm{B}$, and $S$ the fraction of different amino acids (dissimilarity) between two sequences. Phylogenetic trees were constructed using the neighbor-joining method [13]. Distance matrix calculation and tree construction were done with the software package TREECON for Windows [14] version 1.1. 


\section{Sugar permeases}

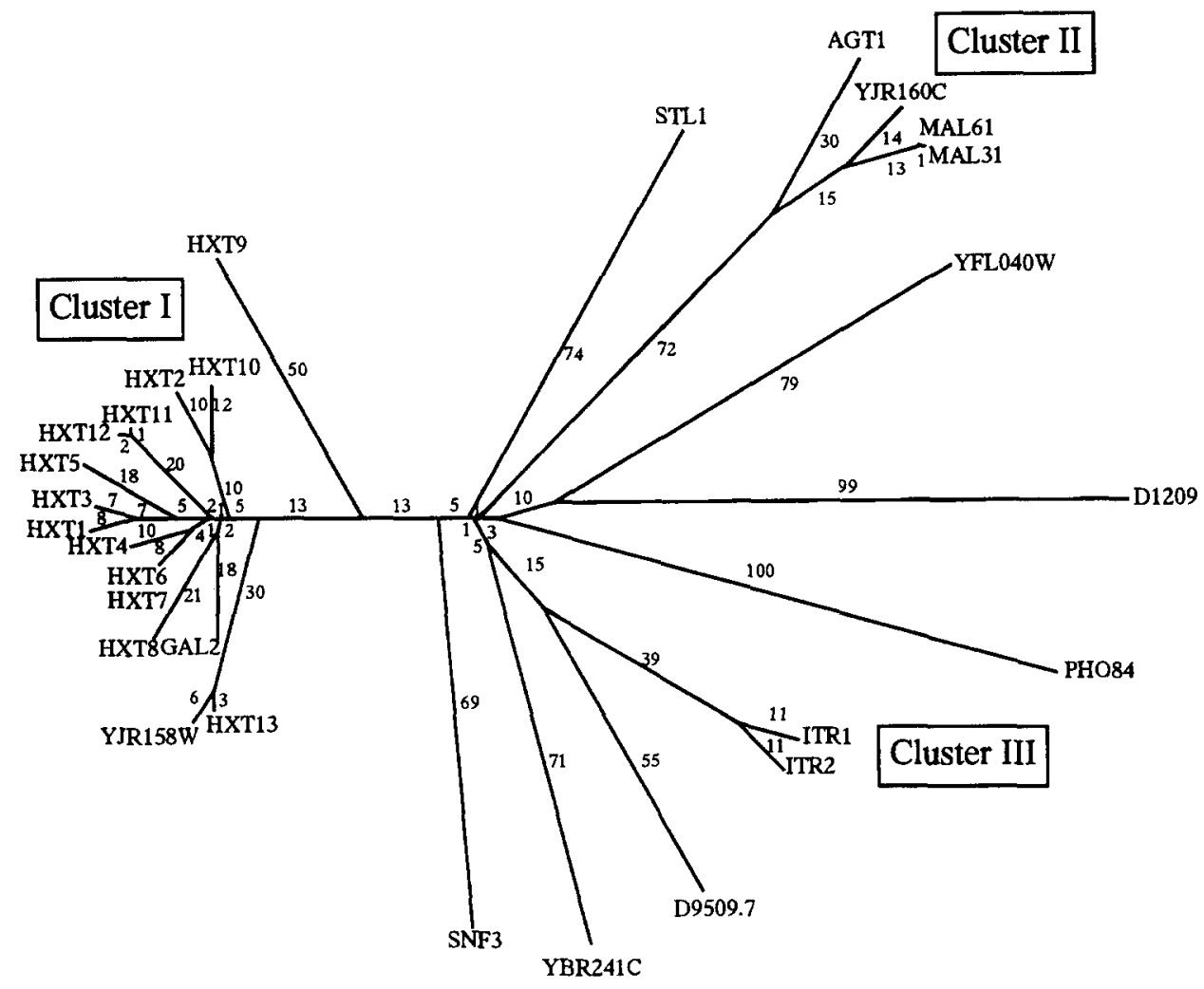

Fir. 1. Phylogenetic tree of the sugar permeases belonging to the MFS. Each number corresponds to the phylogenetic distance $D$ multiplied by a fac tor 100. Proteins are considered to belong to the same cluster if $D \leq 0.9$ (arbitrary value). The exact composition of each cluster can be found in Table 1 .

\section{Results}

\section{3. $\therefore$ Division into families}

After prediction of the number of transmembrane spans, a $\mathrm{BL}$ AST search, and retrieval of the related proteins not yet in ou $r$ dataset, 78 proteins belonging to the MFS were assigned to 16 families. Two frame shifts, probably the result of sequencing errors, were corrected. This resulted in joining ORFs YCL070C, YCL071C, and YCL073C into YCL070-73C, and in joining YIL170W and YIL171W into HXT12. Binary compirisons of all amino acid sequences finally resulted in 17 families, comprising 75 sequences.

In order to update the composition of these families, a new B LAST search and PRSS binary comparisons were carried out in October 1995. This resulted in the same 17 families comprising 100 sequences given in Table 1.

\section{2. Phylogenetic trees}

After alignment of the protein sequences of the sugar and arnino acid permeases, phylogenetic trees were constructed as il ustrated in Figs. 1 and 2.

\section{Discussion}

\subsection{Sugar permeases}

The family of sugar permeases comprises 28 representatives. On the basis of the phylogenetic tree, 21 representatives can be assigned to three different clusters, while the remaining repre- sentatives have no close relatives (Fig. 1, Table 1). Cluster I is the largest cluster and contains 15 proteins, mainly hexose/ glucose permeases (HXT1-HXT13). This is surprising, even though glucose is an important substrate for Saccharomyces cerevisiae. The remaining representatives are a galactose permease (GAL2) and a protein (YJR158W) that is closely related to HXT13 and is thus probably a hexose/glucose permease. Cluster II contains 4 transport proteins, which include two maltose permeases (MAL31 and MAL61), one alpha-glucoside permease (AGT1), and a protein (YJR160C) that is related to the two maltose permeases. Cluster III contains 2 myo-inositol permeases (ITR1 and ITR2). The unclustered proteins consist mainly of permeases with an unknown substrate. Remarkably, the phosphate permease PHO84 belongs to this family of sugar permeases and not to another family that contains the phosphate permease $\mathrm{PHO} 87$.

\subsection{Amino acid permeases}

The family of amino acid permeases is the second largest family and comprises 19 representatives. As can be seen in the phylogenetic tree, 12 representatives can be assigned to 2 clusters (Fig. 2, Table 1). Cluster I contains 9 proteins, including a general amino acid permease (GAP1), branched amino acid permeases (BAP2 and YD9609.02), glutamine permeases (GNP1 and YCL025C), a histidine permease (HIP1), a tryptophan permease (SCM2), and a valine/leucine/isoleucine/tyrosine/tryptophan permease (TAT1). The functions of proteins YD6909.02 and YCL025C can be deduced from their relation- 
ship with BAP2 and GNP1 respectively, but $\mathrm{L} 0555$ is only loosely related to GAP1 and no function can be deduced. Cluster II contains 3 proteins that are basic amino acid permeases (APL1, CAN1, and LYP1). The unclustered proteins consist of a choline permease (CTR1), a proline permease (PUT4), and a GABA (4-aminobutyric acid) permease (UGA4). The remain-

Table I

Families identified within the Major Facilitator Superfamily by BLAST and PRSS

\begin{tabular}{|c|c|c|}
\hline \multicolumn{3}{|c|}{ BLAST and PRSS } \\
\hline $\begin{array}{l}\text { Gene name } \\
\text { (synonyms) }^{a}\end{array}$ & $\begin{array}{l}\text { Access. } \\
\text { No }^{b}\end{array}$ & Function \\
\hline
\end{tabular}

SUGAR PERMEASES

\begin{tabular}{|c|c|c|}
\hline \\
\hline \multicolumn{3}{|l|}{$\frac{\text { CLUSTER I }}{\text { GAL2 (IMP1) }}$} \\
\hline HXT1 (YHR094C) & P32465 & glucose permease, low-affinity \\
\hline HXT2 (YM8270.15) & P23585 & $\begin{array}{l}\text { glucose permease, modulated } \\
\text { affinity }\end{array}$ \\
\hline HXT3 & P32466 & glucose permease, low-affinity \\
\hline $\begin{array}{l}\text { HXT4 (LGT1, } \\
\text { RAG1, YHR092C) }\end{array}$ & P32467 & $\begin{array}{l}\text { glucose permease, moderate- to } \\
\text { low- affinity }\end{array}$ \\
\hline HXT5 (YHR096C) & P38695 & hexose permease \\
\hline HXT6 & P39003 & hexose permease, high-affinity \\
\hline HXT7 & P39004 & hexose permease, high-affinity \\
\hline $\begin{array}{l}\text { HXT8 (YJL214W, } \\
\text { HRA569) }\end{array}$ & P40886 & $\begin{array}{l}\text { similar to hexose permease } \\
\text { HXT4 }\end{array}$ \\
\hline $\begin{array}{l}\text { HXT9 (HXT 14, } \\
\text { N0345) }\end{array}$ & P42833 & hexose permease \\
\hline HXT10 (YFLO11W) & P43581 & hexose permease \\
\hline $\begin{array}{l}\text { HXT11 (YJL219W, } \\
\text { HRC567, LGT3) }\end{array}$ & P40885 & glucose permease, low-affinity \\
\hline HXT12 (YIL170W, & P40441 & similar to sugar permeases \\
\hline $\begin{array}{l}\text { YI9402.06B) } \\
\text { (YIL171W, } \\
\text { YI9402.06A) }\end{array}$ & $\mathrm{P} 40440$ & $\begin{array}{l}\text { (frame shift: YIL170W and } \\
\text { YLL171W joined) }\end{array}$ \\
\hline $\begin{array}{l}\text { HXT13 (YEL069C, } \\
\text { HXT8) }\end{array}$ & P39924 & hexose permease \\
\hline YJR158W & $249658 \times 1$ & similar to sugar permeases \\
\hline \multicolumn{3}{|l|}{ CLUSTER II } \\
\hline AGT1 & $\mathrm{L} 47346 \times 1$ & alpha-glucoside permease \\
\hline $\begin{array}{l}\text { MAL31 (MALK3T, } \\
\text { YBR2116, } \\
\text { YBR298C) }\end{array}$ & P38156 & maltose permease \\
\hline MAL61 (MAL6T) & P15685 & maltose permease \\
\hline YJR160C & $249660 \times 1$ & similar to sugar permeases \\
\hline \multicolumn{3}{|l|}{ CLUSTER III } \\
\hline$\overline{\text { ITR1 }}$ & P30605 & myo-inositol permease (major) \\
\hline ITR2 (HRB612) & P30606 & myo-inositol permease (minor) \\
\hline \multicolumn{3}{|l|}{ UNCLUSTERED } \\
\hline D1209 & $\times 83276 \times 2$ & similar to sugar permeases \\
\hline D9509.7 & $\mathrm{U} 32274 \times 7$ & similar to ITR1 \\
\hline $\begin{array}{l}\text { PHO84 } \\
\text { (YM7056.03) }\end{array}$ & P25297 & $\begin{array}{l}\text { phosphate permease, high- } \\
\text { affinity }\end{array}$ \\
\hline SNF3 & P10870 & similar sugar permeases \\
\hline STL1 & P39932 & sugar permease \\
\hline $\begin{array}{l}\text { YBR241C } \\
\text { (YBR1625) }\end{array}$ & P38142 & similar to sugar permeases \\
\hline YFL040W & P43562 & similar to sugar permeases \\
\hline
\end{tabular}

AMINO ACID PERMEASES

$\begin{array}{lll}\begin{array}{l}\text { CLUSTERJ } \\ \text { BAP2 (YBR068C, } \\ \text { YBR0629) }\end{array} & \text { P38084 } & \begin{array}{l}\text { leucine / valine / isoleucine } \\ \text { permease }\end{array} \\ \begin{array}{ll}\text { GAP1 (YKR039W) } \\ \text { GNP1 }\end{array} & \begin{array}{l}\text { P19145 } \\ \text { U33057xal amino acid permease } \\ \text { glutamine permease, high- } \\ \text { affinity }\end{array} \\ \text { HIP1 (G7572) } & \text { P06775 } & \begin{array}{l}\text { histidine permease } \\ \text { similar to GAP1 }\end{array} \\ \text { L0555 } & \mathbf{Z 4 7 9 7 3 \times 1 0} \\ \text { TAT2 (SCM2, } & \text { P38967 } & \begin{array}{l}\text { tryptophan permease, high- } \\ \text { affinity }\end{array}\end{array}$

ing proteins (YBR132C, YD8358.14, YFL055W, and YKL174C) belong to the amino acid permease family, but their exact substrate is not known.

\subsection{Multidrug resistance proteins}

The multidrug resistance proteins (MDR) are subdivided

Table 1

(continued)

\begin{tabular}{|c|c|c|}
\hline \multicolumn{3}{|c|}{ (continued) } \\
\hline $\begin{array}{l}\text { Gene name } \\
\text { (synonyms) }\end{array}$ & $\begin{array}{l}\text { Access. } \\
\text { No }^{b}\end{array}$ & Function \\
\hline $\begin{array}{l}\text { TAT1 (VAP1, } \\
\text { TAP1, YBR710, } \\
\text { YBR069C) }\end{array}$ & P38085 & $\begin{array}{l}\text { valine / leucine / isoleucine / } \\
\text { tyrosine / tryptophan permease }\end{array}$ \\
\hline YCL025C (YCC5) & P25376 & similar to GNP1 \\
\hline PAP1 (YD9609.0) & P41815 & $\begin{array}{l}\text { similar to amino acid } \\
\text { permeases }\end{array}$ \\
\hline \multicolumn{3}{|l|}{ CLUSTER II } \\
\hline ALP1 (APLI) & P38971 & $\begin{array}{l}\text { similar to basic amino acid } \\
\text { permeases CAN1 and LYP1 }\end{array}$ \\
\hline CAN1 (YEL063C) & P04817 & $\begin{array}{l}\text { arginine / lysine / omithine } \\
\text { permease }\end{array}$ \\
\hline LYP1 & P32487 & lysine permease, high-affinity \\
\hline \multicolumn{3}{|l|}{ UNCLUSTERED } \\
\hline CTR1 (HNM1) & P19807 & choline permease \\
\hline PUT4 & P15380 & proline permease, high-affinity \\
\hline UGA4 & P32837 & $\begin{array}{l}\text { GABA-specific permease, } \\
\text { high-affinity }\end{array}$ \\
\hline $\begin{array}{l}\text { YBR132C } \\
\text { (YBR1007) }\end{array}$ & P38090 & $\begin{array}{l}\text { similar to amino acid } \\
\text { permeases }\end{array}$ \\
\hline YD8358.14 & $Z 50046 \times 14$ & $\begin{array}{l}\text { similar to amino acid } \\
\text { permeases }\end{array}$ \\
\hline YFL055W & P43548 & $\begin{array}{l}\text { similar to amino acid } \\
\text { permeases }\end{array}$ \\
\hline YKL174C & P36029 & similar to CTRI permease \\
\hline
\end{tabular}

MULTIDRUG RESISTANCE PROTEINS, FAMILY 1

\begin{tabular}{|c|c|c|}
\hline HOL1 & L42348x 1 & $\begin{array}{l}\text { similar to YBR043C and } \\
\text { YHR048C }\end{array}$ \\
\hline P9584.7 & U28371x3 & similar to YBR008C \\
\hline $\begin{array}{l}\text { YBR008C } \\
\text { (YBR0120) }\end{array}$ & P38124 & similar to multidrug permeases \\
\hline $\begin{array}{l}\text { YBR043C } \\
\text { (YBR0413) }\end{array}$ & P38227 & similar to multidrug permeases \\
\hline $\begin{array}{l}\text { YBR180W } \\
\text { (YBR1242) }\end{array}$ & P38125 & similar to multidrug permeases \\
\hline $\begin{array}{l}\text { YHR048W } \\
\text { YIL120W } \\
\text { (I8277.09) }\end{array}$ & $\begin{array}{l}\text { P38776 } \\
\text { P40475 }\end{array}$ & $\begin{array}{l}\text { similar to multidrug permeases } \\
\text { similar to multidrug permeases }\end{array}$ \\
\hline $\begin{array}{l}\text { YIL121W } \\
(I 8277,08)\end{array}$ & P40474 & similar YIL120W \\
\hline YNL1613 & U12141x3 & similar to multidrug permeases \\
\hline
\end{tabular}

MULTIDRUG RESISTANCE PROTEINS, FAMILY 2

\begin{tabular}{|c|c|c|}
\hline $\begin{array}{l}\text { ATR1 (SNQ1, } \\
\text { YM83390.03) }\end{array}$ & P13090 & aminotriazole resistance protein \\
\hline ORF_886916 & $\times 87941 \times 8$ & similar to multidrug permeases \\
\hline $\begin{array}{l}\text { SGE1 (NOR1, } \\
\text { P9677.3) }\end{array}$ & P33335 & crystal violet resistance protein \\
\hline $\begin{array}{l}\text { YBR293W } \\
\text { (YBR2109) }\end{array}$ & P38358 & similar to multidrug permeases \\
\hline YCL069W & P25594 & $\begin{array}{l}\text { similar to bacterial multidrug } \\
\text { resistance proteins }\end{array}$ \\
\hline $\begin{array}{l}\text { YCL070-73C } \\
\text { (YCL070C, } \\
\text { YCL071C, } \\
\text { YCL073C) }\end{array}$ & P25596 & $\begin{array}{l}\text { similar to YKR106 (frame shift: } \\
\text { YCL070C, YCL071C, and } \\
\text { YCL073C joined) }\end{array}$ \\
\hline YD9727.14 & Z48758x14 & similar to multidrug permeases \\
\hline YEL065W & P39980 & similar to multidrug permeases \\
\hline YHL040C & P38731 & similar to YKR106W \\
\hline YHL047C & P38724 & similar to YKR106W \\
\hline YKR105C & P36172 & similar to SGE1 \\
\hline
\end{tabular}


Table I

(continued)

\begin{tabular}{lll} 
& \multicolumn{2}{c}{ (continued) } \\
\hline $\begin{array}{l}\text { Gene name } \\
\text { (synonyms) }\end{array}$ & $\begin{array}{l}\text { Access. } \\
\mathrm{No}^{\mathrm{b}}\end{array}$ & Function \\
\hline YKR106W & $\mathrm{P} 36173$ & similar to YCL070-73C \\
YM8021.05 & $\mathrm{Z} 49259 \times 15$ & similar to multidrug permeases \\
YM9582.13 & $\mathrm{Z} 49259 \times 15$ & similar to multidrug permeases
\end{tabular}

URACIL/ALLANTOIN PERMEASES

$\begin{array}{lll}\text { DAL4 (YIR028W) } & \text { Q04895 } & \text { allantoin permease } \\ \text { FUR4 (YBRO303, } & \text { P05316 } & \text { uracil permease } \\ \text { YBR021W) } & & \\ \text { L8083.2 } & \text { U19027 } 14 & \text { similar to FUR4 and DAL4 } \\ \text { YBL042C } & \text { P38196 } & \text { similar to FUR4 and DAL4 } \\ \text { (YBL0406) } & & \end{array}$

ALLANTOATE PERMEASES

$\begin{array}{lll}\begin{array}{l}\text { DAL5 (UREP1, } \\ \text { YJR152W) }\end{array} & \text { P15365 } & \text { allantoate permease } \\ \text { L0578 } & \text { Z47973x16 } & \text { similar to DAL5 } \\ \text { YAL067C } & \text { P39709 } & \text { similar to DAL5 } \\ \text { YCR028C } & \text { P25621 } & \text { similar to DAL5 } \\ \text { YIL166C } & \text { P40445 } & \text { similar to DAL5 } \\ \text { (Y19402.09) } & & \end{array}$

PHOSPHATE PERMEASES

$\begin{array}{lll}\text { N2052 } & \text { P27514 } & \begin{array}{l}\text { similar to PHO87 } \\ \text { phosphate permease }\end{array} \\ \begin{array}{l}\text { YCR037C) } \\ \text { YJL198W (J0336) }\end{array} & \text { P39535 } & \text { similar to PHO87 }\end{array}$

PURINE/CYTOSINE PERMEASES

$\begin{array}{lll}\begin{array}{l}\text { FCY2 (YER056C) } \\ \text { YER060W }\end{array} & \text { P17064 } & \begin{array}{l}\text { cytosine / purine permease } \\ \text { similar to FCY2 }\end{array} \\ & \text { PROTEIN PERMEASES } \\ \text { SEC61 (L3502.5) } & \text { P32915 } & \begin{array}{l}\text { component of ER protein- } \\ \text { translocation complex } \\ \text { similar to SEC61 }\end{array} \\ \begin{array}{l}\text { YBR283C } \\ \text { (YBR2020) }\end{array} & \text { P38353 } & \end{array}$

PEPTIDE PERMEASES

PTR2 (YKR413C, P32901 peptide permease YKR093W)

\section{POTASSIUM PERMEASES}

\begin{tabular}{|c|c|c|}
\hline TRK1 (YJL129C) & P12685 & $\begin{array}{l}\text { potassium permease, high } \\
\text { affinity }\end{array}$ \\
\hline $\begin{array}{l}\text { TRK2 (RPD2, } \\
\text { YKR050W) }\end{array}$ & P28584 & $\begin{array}{l}\text { potassium permease, moderate } \\
\text { affinity }\end{array}$ \\
\hline \multicolumn{3}{|c|}{ SULFATE PERMEASES } \\
\hline $\begin{array}{l}\text { SUL1 (SFP, } \\
\text { YBR2110, } \\
\text { YBR294W) }\end{array}$ & P38359 & sulfate permease, high-affinity \\
\hline YP9723.03 (LPZ3C) & $248951 \times 3$ & $\begin{array}{l}\text { similar to high affinity sulfate } \\
\text { transporter }\end{array}$ \\
\hline \multicolumn{3}{|c|}{ UREA PERMEASES } \\
\hline DUR3 (YHL016C) & P33413 & urea permease \\
\hline
\end{tabular}

in to two families: MDR 1 and MDR 2 (Table 1), which comprise 9 and 24 representatives respectively. This slightly modifies the conclusions of a recent study of Goffeau et al. (unpublished results), in which all multidrug resistance proteins are in one family, divided into 3 clusters. Taking into account the

\begin{tabular}{|c|c|c|}
\hline $\begin{array}{l}\text { Gene name } \\
\text { (synonyms) }^{\mathrm{a}}\end{array}$ & $\begin{array}{l}\text { Access. } \\
\mathrm{No}^{\mathrm{b}}\end{array}$ & Function \\
\hline \multicolumn{3}{|c|}{ UNKNOWN FUNCTION, FAMILY 1} \\
\hline SYG1 (YIL047C) & P40964 & similar to $\mathrm{N} 2052$ \\
\hline \multicolumn{3}{|c|}{ UNKNOWN FUNCTION, FAMILY 2} \\
\hline $\begin{array}{l}\text { PTM1 (YKL252, } \\
\text { YKL039W) }\end{array}$ & P32857 & similar to YHL017W \\
\hline YHL017W & P38745 & similar to PTM1 \\
\hline
\end{tabular}

UNKNOWN FUNCTION, FAMILY 3

$\begin{array}{lll}\begin{array}{l}\text { YBL089W } \\ \text { (YBL0703) }\end{array} & \text { P38176 } & \text { similar to YER119C } \\ \text { YEL064C } & \text { P39981 } & \text { similar to YBL089W } \\ \text { YER119C } & \text { P40074 } & \text { similar to YBL089W } \\ \text { YL088C (19910.08) } & \text { P40501 } & \text { similar to YBL089W }\end{array}$

UNKNOWN FUNCTION, FAMILY 4

\begin{tabular}{|c|c|c|}
\hline JEN1 (YKL217W) & P36035 & $\begin{array}{l}\text { similar to bacterial proline / } \\
\text { betaine and mammalian } \\
\mathrm{Na}^{+} / \text {carboxylic acid permeases }\end{array}$ \\
\hline \multicolumn{3}{|c|}{$\begin{array}{l}\text { Families are based on BLAST and PRSS, clusters within } \\
\text { families are based on phylogenetic trees. " Gene names and } \\
\text { synonyms are according to the YPD database at URL } \\
\text { http://www.proteome.com/YPDhome.html . 'Accession } \\
\text { numbers are from SwissProt if started by P or Q, otherwise } \\
\text { from GenBank }\end{array}$} \\
\hline
\end{tabular}

number of predicted transmembrane spans (Goffeau et al., unpublished results), which is 12 for MDR 1 and 14 for MDR 2 , it seems that the assignment of the multidrug resistance proteins to two families instead of one family is correct.

4.4. Other permease families with known function

As can be seen in Table 1, the uracil/allantoin permease family comprises 4 representatives. The allantoin permease (DAL4) and the uracil permease (FUR4) are more closely related to each other than to YBL042W and L8083.2 (unpublished results). The allantoate permease family contains 5 representatives. The allantoate permeases DAL5 and L0578 are more related to each other than to the other members, and so are YCR028C and YAL067C (unpublished results). The phosphate permease family contains 3 representatives, N2052, PHO87, and YJL198W, but not PHO84 which is a member of the sugar permease family. Based on the BLAST results, SYG1 also belongs to the phosphate permease family, but it was excluded on the basis of the PRSS results and put in a separate family with unknown function. The purine/cytosine, protein, potassium, and sulfate permease families contain only 2 representatives each, while the peptide and urea permease families consist of only one member each.

\subsection{Permease families with unknown function}

The families listed as unknown function bare no similarity to proteins with a known function in yeast or other organisms. Four such families are listed in Table 1 with 1,2 , 4, and 1 member(s).

\section{Conclusions}

The present work demonstrates the power of the phylogen- 


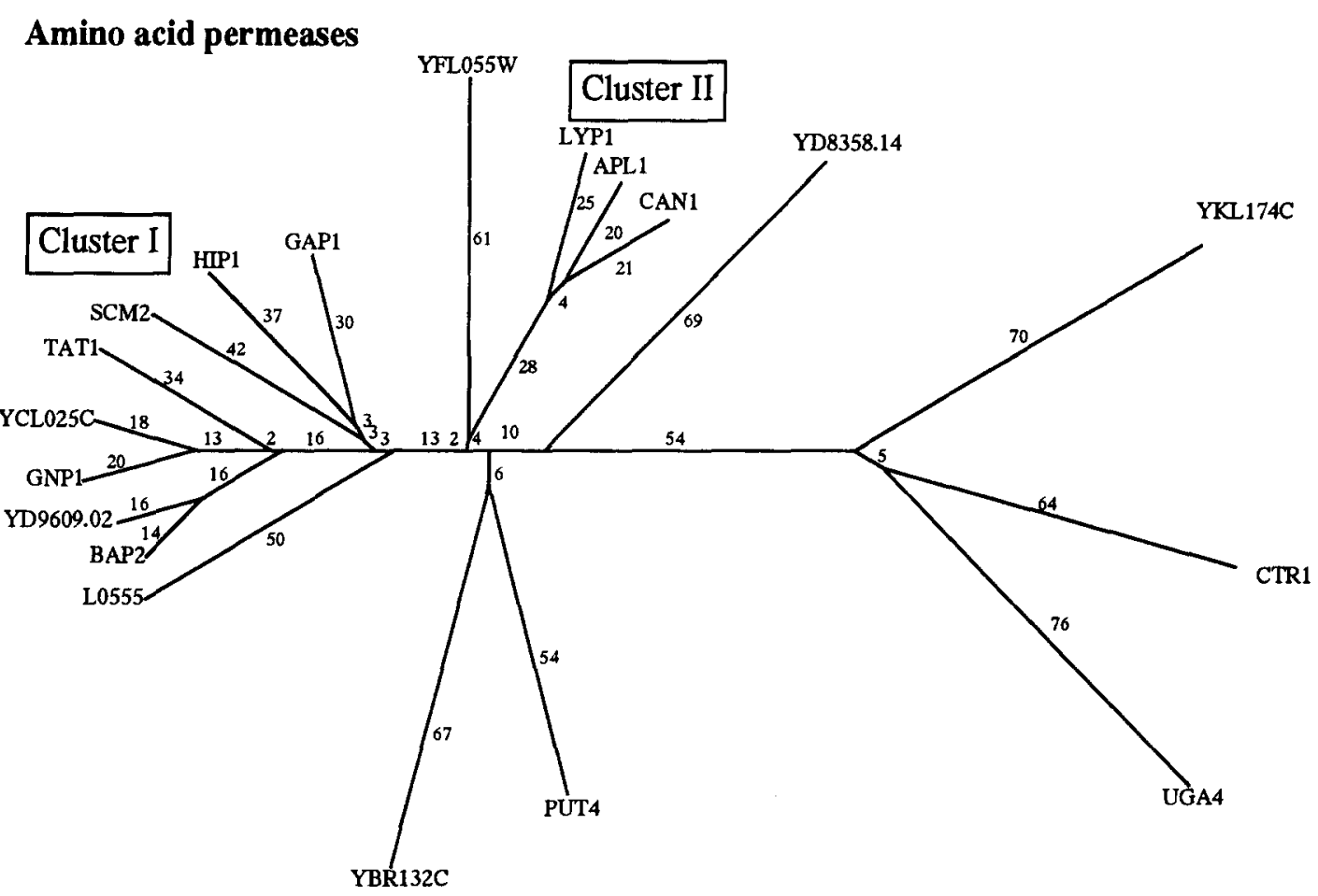

Fig. 2. Phylogenetic tree of the amino acid permeases belonging to the MFS. Conventions as in Fig. 1.

etic analysis of membrane proteins, pioneered by [2], as applied to the data generated by the systematic sequencing of the yeast genome [15]. This approach has allowed to distinguish 17 families within the yeast members of the MFS proteins. This is a considerable increase in the number of MFS families which so far was estimated to be 6 for all species combined [1]. At completion of this study (October 1995) approximately 5000 yeast ORFs were available, whereas the complete genome is estimated to comprise 6400 ORFs [3]. Taking into account that 100 MFS proteins were identified in the present study, the total number in the yeast genome can be estimated at 128. The additional members still to be revealed will most probably belong to the 17 families presently assigned. Our approach has allowed us to suggest functions by clustering, e.g. YJR 158W which clusters with the hexose/glucose permeases in the sugar permease family. Interestingly, 4 families have been found with an unknown function (Unknown $1-4$ in Table 1). Even within families with a known function, it has not been possible to suggest a function for all proteins by clustering, e.g. YFL040W in the sugar permease family.

While this work was in progress we became aware of a classification of yeast transport proteins by Bruno André (personal communication).

Acknowledgements: This research was supported by the Programme on Interuniversity Poles of Attraction of the Office for Scientific, Cultural and Technical Affairs of the Belgian State (contracts no. 18 and 23).

\section{References}

[1] Marger, M.D. and Saier, M.H. (1993) Trends Biochem. Sci. 18, $13-20$.

[2] Saier, M.H. (1994) Microbiol. Rev. 58, 71-93.

[3] Goffeau, A., Slonimski, P., Nakai, K. and Risler, J.-L. (1993) Yeast 9, 691-702.

[4] Goffeau, A., Nakai, K., Slonimski, P. and Risler, J.-L. (1993) FEBS Lett. 325, 112-117.

[5] Williams, N. (1995) Science 268, 1560-1561.

[6] Klein, P., Kanehisha, M. and DeLisi, C. (1985) Biochim. Biophys. Acta $815,468-476$.

[7] Altschul, S.F., Gish, W., Miller, W., Myers, E.W. and Lipman, D.J. (1990) J. Mol. Biol. 215, 403-410.

[8] Pearson, W.R. (1990) Methods Enzymol. 183, 63-68.

[9] Pearson, W.R. and Lipman, D.J. (1988) Proc. Natl. Acad. Sci. USA $85,2444-2448$.

[10] Wisconsin Sequence Analysis Package, Version 8 (1994) Program Manual, Genetics Computer Group, 575 Science Drive, Madison, WI 53711, USA.

[11] Zuckerkandl, E. and Pauling, L. (1965) in: Evolving genes and proteins (Bruson, V. and Vogel, H.J., Eds.) pp. 97-166, Academic Press, New York.

[12] Dickerson, R.E. (1971) J. Mol. Evol. 1, 26-45.

[13] Saitou, N. and Nei, M. (1987) Mol. Biol. Evol. 4, 406425.

[14] Van de Peer, Y. and De Wachter, R. (1994) Comput. Applic. Biosci. 10, 569-570.

[15] Goffeau, A. (1994) Nature 369, 101-102. 